\title{
DEÁK JÓZSEF
}

\section{A terrorizmus természete és az ellene történő fellépés nehézségei Oroszországban a Szovjetunió szétesésétől napjainkig}

Az Oroszországi Föderáció 2009 májusában aláírt, Az Oroszországi Föderáció 2020-ig szóló nemzetbiztonsági stratégiája $a^{l}$ címü elnöki rendeletéből kiderül, hogy az ország biztonságát - az állam- és közbiztonságát érintő veszélyforrások felsorolásában rögtön a külföldi hírszerző és speciális szolgálatok Oroszország ellen irányuló mesterkedéseit ${ }^{2}$ követő veszélyforrásként - a terrorista szervezetek, csoportok és magányos terroristák tevékenysége fenyegeti.

Az ország közelmúltjában - a Szovjetunió szétesése után - elkövetett több tragikus terrorcselekmény is ezt támasztja alá. Mindezek fényében például az e szempontból legveszélyeztetettebb észak-kaukázusi régióban kialakult helyzetre is tekintettel miként látja az Oroszországi Föderáció a terrorizmus kérdéskörét? Hogyan értelmezik a fogalmát, miben látják a gyökereit, Oroszország történelmi felelősségét, és mennyiben hárítják külföldi államok titkosszolgálataira a terroristák, extremisták, szeparatisták ösztönzését? Melyek a terrorizmus megelözésének lehetséges és melyek a bevált módozatai? Oroszország terrorelhárító erői eddig milyen sikereket könyvelhetnek el? Jelenleg hogyan értékelik az extremizmus és a terrorizmus büntetőjogi felelősségét? Megvalósítható-e a terrorizmus jövő nélkül, Oroszország terrorizmus nélkül szép óhaj? Hogyan tekintenek a terrorizmus nemzetközi összefüggéseire és azokra az államokra, amelyek politikai céljaik szolgálatába állítják a terrorizmust?

$1 \mathrm{O}$ sztrategii nacionalnoj bezopasznosztyi Roszijszkoj Federaciji do 2020 goda (Az Oroszországi Föderáció 2020-ig szóló nemzetbiztonsági stratégiája). http://www.scrf.gov.ru/documents/1/99.html

2 2014-ben speciális műveletek következtében külföldi titkosszolgálatok ötvenkét munkatársát és kétszázkilenc ügynökét sikerült leleplezni az orosz RIA Novosztyi hírügynökség adatai szerint. http://www.rsuh.ru/antiterror/ 


\section{Az Oroszországot fenyegető terrorveszélyek}

„Az alapvető emberi és állampolgári szabadságjogok védelmét az Oroszországi Föderáció állama garantálja. " 3 Az alaptörvényben az élethez való jog követi az első, a törvény és bíróság elötti egyenlőséget rögzítő alapjogot. Márpedig a terrorcselekmények természetéből adódóan a kitervelöik céljaihoz vezetö úton a legnagyobb veszélyt a testi épségre, az emberi életre jelentik, mivel a közvélemény figyelme legbiztosabban a tragikus terrorcselekmények emberi áldozataival, azok számával, életkorával ragadható meg, hiszen az anyagi veszteség, legyen bármekkora, pótolható...

Milyen a terrorizmusból kiinduló veszélyekkel számol az Oroszországi Föderáció? Az idézett nemzetbiztonsági stratégia szerint a terroristák tevékenysége irányulhat az ország alkotmányos rendjének erőszakos megváltoztatására; az államhatalom normális müködésének megzavarására (ideértve az állami, politikai és társadalmi vezetők elleni merényleteket); a társadalom normális müködését szavatoló katonai objektumok, ipari létesítmények, vállalatok és intézmények megsemmisítésére; a lakosság megfélemlítésére, egyebek között atom-, vegyi fegyver, vagy veszélyes radioaktív, vegyi és biológiai anyagok alkalmazásával, ennek kilátásba helyezésével. Az országra leselkedő nemzetbiztonsági veszélyek felsorolásában a terrorizmus után az extremizmus következik, amely a nacionalista, vallási és egyéb etnikai szervezeteknek, struktúráknak a föderáció nemzeti és területi egysége megbontására, az ország belpolitikai és társadalmi rendjének destabilizálására irányul.

Oroszország 2014-ben elfogadott katonai doktrínája is a legfőbb külső katonai fenyegetések egyikének nevezi a globális extremizmus (terrorizmus) növekvő veszélyét, és a nem elég hatékony nemzetközi antiterrorista fellépés következtében jelentkező új formáit, reális veszélyként jelentkezik a terrorcselekmények során a radioaktív és mérgező vegyi anyagok alkalmazása. ${ }^{4} \mathrm{~A}$ biztonságról szóló szövetségi törvény is együtt említi ezt a két veszélyforrást, felhatalmazva az elnököt arra, hogy az Oroszországi Föderáció törvényeinek megfelelően intézkedéseket hozzon az állampolgárok védelmében, a bűnöző és egyéb jogellenes magatartások, a terrorizmus és extremizmus megnyilvánulásai ellen. ${ }^{5}$

\footnotetext{
3 Konsztitucija Rosszijszkoj Federaciji (az Oroszországi Föderáció alkotmánya) 45. § 1. bekezdés. http://constitution.kremlin.ru/

4 Voennaja Doktrina Rosszijszkoj Federaciji. http://www.rg.ru/2014/12/30/doktrina-dok.html

5 Federalnüj zakon „O bezopasznosztyi” (szövetségi törvény a biztonságról).

http://www.scrf.gov.ru/documents/1/111.html
} 


\section{A terrorizmus fogalma}

A terrorizmus elleni küzdelem problémájának kutatása Oroszországban jelenleg két fő irány szerint zajlik. Az első megközelítés a terrorizmust mint politikai, nemzetközi jogi kategóriát vizsgálja, a másik - az utóbbi években megjelenő - tudományos irányzat pedig a terrorizmust szigorúan csak büntetőjogi, kriminológiai problémaként taglalja ${ }^{6}$

A terrorizmus: megfélemlítés, bizonyos cél elérésére. Ez különbözteti meg más, hasonló büntetőjogi tényállástól, kategóriától. A terrorizmus mint az extremizmus legszélsőségesebb megnyilvánulása, az ellenség gyöngítésének módja, a büncselekmény valamilyen fizikai objektumának (objektumainak) megsemmisítésével, rongálásával és a szemben álló félre történő pszichikai nyomással. Tehát korántsem pusztán állami vezetők elleni merényletet takar, vagy forradalmárok, fegyveres lázadók támadását a politikai céljaik eléréséhez szükséges anyagiak megszerzésére. Ezért nem számít terrorizmusnak a Sztálin és Kamo, azaz Szemjon Ter-Petrjoszján vezette fegyveresek 1907. június 13-i akciója a tbiliszi Jereván téren, ahol kézigránátokkal rátámadva az állami bank konvojára és emberek tucatjait megölve, megsebesítve, bő negyedmillió rubelt raboltak, külföldön munkálkodó bolsevik vezetöiknek kijuttatva. A politikai indíték, a rablás és a többtucatnyi emberi élet kioltása ellenére sem beszélhetünk terrorizmusról, mivel az utóbbi lényege a tartós félelemkeltés, elrettentés valamilyen meghatározott, föként pszichológiai és politikai cél elérése érdekében. Napjainkban szintén nem kevés köztörvényes bünbanda bújik - némi félelmet is generálva - forradalmi, politikai frázisok mögé, miközben a pillanatnyi haszonszerzésen kívül nincs megfélemlítéssel elérendő távlati céljuk.?

Az 1996 óta hatályos oroszországi büntető törvénykönyv 205. §-a ${ }^{8}$ szerint „,Terrorista cselekménynek számít: emberek halálával, jelentős anyagi kárral járó vagy egyéb, veszélyes társadalmi következményekkel fenyegetö támadás, robbantás, gyújtogatás vagy más cselekmény elkövetése, ha ezeket a társadalmi rend megsértése céljából hajtják végre vagy a hatalmi szervek döntéshozatalának befolyásolását célozza vagy a fenti cselekményekkel történö fenyegetés, ugyanazon célok elérésére történik”. Elkövetỏjét alapesetben nyolctól tizenöt évig terjedő szabadságvesztés-büntetéssel fenyegetik.

\footnotetext{
6 Mihejev Ivan Rudolfovics: Terrorizm: ponjatyie, otvetsztvennoszty, preduprezsgyenyije (Terrorizmus: értelmezés, felelősség, megelőzés). http://www.kiev-security.org.ua/box/4/123.shtml

7 Kratkaja isztorija terrorizma (A terrorizmus rövid története). http://molevashovo.spb.ru/publ/info/936

8 Kodekszi i zakoni RF (Az Oroszországi Föderáció kódexei és törvényei).

http://www.zakonrf.info/uk/205/
} 


\section{Gyökerek, eredet}

Az oroszországi terrorizmus gyökerei is igen mélyre nyúlnak. A jelenség közvetlenül ered egyebek között az orosz társadalom történelme folyamán kialakult, extremista, türelmetlen, társadalom-lélektani beállítottságából gyakran előtörő lázadó, anarchista orosz mentalitásból. Történelmi tradíciókra tekinthet vissza a jól szervezett, konspirált, szerteágazó, és tömeges terrorizmus formájában (például a Népakarat, az eszerek - bal- és jobboldali szocialrevolucionyerek, azaz szociálforradalmárok -, bolsevikok és mások harci szerveződései, rémtettei). Oroszország soknemzetiségü és -vallású állam, napjainkban azonban a nemzetiségei közötti kapcsolatok szempontjából nem a legjobb időket éli. Emellett az országban mintegy húszmillió muzulmán él, jó részük erőszakos, különösen kegyetlen, szélsőségesen radikális vahabita.

Oroszország - elsősorban kaukázusi - népeinél, etnikai csoportjainál a felvetődő nehézségek megoldásában az erőszakos, az extremista-terrorista módszerek gyakran a nemzeti kultúra és vallás szerves elemei. Nem véletlen, hogy a terrorcselekmények elkövetőinek jelentős része a kaukázusi köztársaságokból származik, és ez a régió a permanens feszültség, véres összetűzések fészkévé vált. A föderációban a terrorizmus belső okai között szintén meghatározó, hogy az állam müködésében még nem eléggé fejlettek a polgári társadalmi tradíciók. A lakosság meghatározó részével egybecsengő szakértői vélemények szerint az oroszországi terrorizmus alapvető külső gerjesztő okai között szerepel Oroszország hirtelen zártból abszolút nyitott állammá válása, ez kiszolgáltatottá tette a társadalmat minden, a Nyugat irányából érkező negatív jelenségnek. Egyben pedig magával hozta az ország területének a külföldi és a nemzetközi terrorizmus gyakorlóterévé válása veszélyét, és itt kell feltétlenül megemlíteni az oroszországi instabilitásnak és szeparatizmusnak a nyugati titkosszolgálatok általi minden erővel történő elismerését, népszerüsítését. ${ }^{9}$

$\mathrm{Az}$ orosz belügyminisztérium értékelése szerint a nemzetközi terrorszervezetek tevékenységéhez mintegy másfél ezer orosz származású ember kapcsolódik. Több mint háromszáz büntetöügy zajlik olyanok ellen, akik csatlakoztak egyebek között az Iszlám Államhoz, vagy a Tádzsikisztánban betiltott Hizb ut-Tahrir szélsőséges szervezethez. ${ }^{10}$

\footnotetext{
9 Kratkaja isztorija... i. m.

10 Nauka i obrazovanyije protyiv terrora (Tudomány és oktatás a terror ellen).

http://www.rsuh.ru/antiterror/
} 


\section{Terrorizmustipológiák}

A terrorizmus rendszerezésében a téma rendkívüli bonyolultsága, formájának sokfélesége, az értékelések politikai ellentmondásai miatt Oroszországban sem született egységes megközelítés. ${ }^{11}$ Viktor Vasziljevics Lunyejev ${ }^{12}$ kutatásai szerint a közelmúltban a politikai és ideológiai terrorizmus egészen különös esetei léteztek Oroszországban:

1. Forradalmi és ellenforradalmi (vörös- és fehér-) terror, a forradalom és a polgárháború idején.

2. Állami és belső terror, a sztálini politikai és az utána következő megtorlásokkor.

3. Állami és nemzetközi terror, a szovjethatalom fennállásának egész idején.

A terrorizmus e formáit megnyilvánulásuk idején és azóta sem kriminalizálta a társadalom és az állam politikai terrorként.

Napjainkban a terrorista tevékenység más formái müködnek:

a) Politikai indíttatású terror az állami és társadalmi személyiségek, illetve a hatalom képviselőinek meggyilkolása útján. E tekintetben különös veszélyt jelentenek a különféle politikai erők legszélsőségesebb csoportjai.

b) Szervezett bünözői körök köztörvényes terrorja az állam és képviselői ellen, a bünügyek kivizsgálásának megzavarására, a szigorú büntetőpolitika folytatásának megakadályozására, az igazságszolgáltatási szervek legaktívabb munkatársainak likvidálására.

c) A szeparatisták nacionalista terrorja, a politikai vagy gazdasági különválás céljából a hatalom szövetségi szervei müködésének megbénítására.

d) A gépeltérítők légi terrorizmusa túszejtés, pénz-, fegyver-, kábítószerszerzés és másik országba való szabad repülésüket lehetővé tevő követeléseik teljesítésére.

e) Nemzetközi terrorizmus, külföldi állam képviselöinek megölése háborúprovokálás vagy egyéb nemzetközi bonyodalomkeltés céljából.

Mentelejeva $^{13}$ tipizáláskor - elismerve katonai, hadicselekmények esetén az államterror és -erőszak létezését - abból indul ki, hogy a terrorizmus legáltalánosabb jelentésében többnyire politikai, etnikai vagy vallási kisebbséghez

\footnotetext{
11 Mihejev Ivan Rudolfovics: i. m

12 Kratkaja isztorija... i. m.

13 Uo.
} 
tartozók pontszerü, egy-egy konkrét helyszínen megvalósuló terrorcselekményeihez kapcsolódik.

Ideológiai terror: azok követik el, akik valamilyen okból a hivatalos, legitim politika keretein kívül rekedtek. Képviselői váltogatják a társadalmi berendezkedéseket, mert ami az egyikben illegális, a másikban szabadon virágozhat, parlamentáris körülmények között vezeti az országot.

Etnikai terror: alanya egy többségi csoporthoz tartozó törpe nemzeti-etnikai csoport, amely nem engedélyezi az etnikai önrendelkezési jogot. Itt találkozhatunk rasszizmussal is.

Vallási terror: alanya egy kisebbségi vagy a többségi vallás kiábrándult aktív magja. A teológiai színezetü forradalmi „rasszizmus” megveti más vallás „hitetlen” képviselőit. A vallási terrorizmus különleges megnyilvánulási formája, amikor is az erőszakot a „kiválasztottak”, „megmentettek” gyakorolják az elátkozottakkal szemben.

Kriminális terror: viszonylag ritka jelenség, ha a bünözőcsoport kifejezetten ideológiai, etnikai vagy vallási jellemzőkkel bír.

Individuális terror: az individuum racionálisan és ideológiailag nem megalapozott, egzisztenciális-szubjektív tiltakozása, fellázadása a társadalom ellen. A terrorcselekmény elözménye többnyire pszichikai sérülés,vagy az keletkezik az elkövetésekor.

Más csoportosításokban ${ }^{14}$ az előbbieken túl hasonlóan jelentős megfélemlítő formák még a szociális, az információs, a gazdasági, az önzetlen vagy fanatikus, a szuicid, a technológiai, az államellenes, a pszichikai, az ökológiai, az atom-, a tengeri és a kiber- stb. terrorizmus.

\section{Terror és terrorellenes közelmúlt észak-kaukázusi kitekintéssel}

Az oroszországi terrorizmus napjainkig tartó tragédiáinak sorozatát a szovjet rendszerváltozás idején, 1991. május 30-án Dagesztánban, a Moszkva-Baku között közlekedő vonat felrobbantása nyitotta meg tizenegy utas halálával. Alig egy év múltán Borisz Jelcin elnök ellen követtek el sikertelen merényletet. A rendszerváltozás óta bekövetkezett terrorcselekmény-áradat puszta felsorolása helyett célszerűbb vizsgálni a terror elleni fellépés tényeit, hatékonyságának növekedését.

14 Mihejev Ivan Rudolfovics: i. m. 
1998. július 25-én hozták meg az első szövetségi törvényt a terrorizmus elleni harcról. ${ }^{15}$ Ekkoriban még úgy tekintettek a terrorizmussal kapcsolatos kérdéskörre, mint az Oroszország nemzetbiztonságát fenyegető reális, bár egyre növekvő veszélyre - a sok közül. A szinte változatlan intenzitással bekövetkező terrorcselekmények nyomán a törvény mind több kiegészítésre szorult. Az idő múlásával gyarapodott a terrorcselekmények kutatóinak tábora, közülük sokan a téma szakértőivé váltak, és jelezték, hogy a terrorizmus elleni küzdelemhez új törvényre, struktúrákra van szükség. ${ }^{16}$

2006. március 6-án meg is született a terrorizmus elleni fellépésről szóló szövetségi törvény. A Nemzeti Antiterrorista Bizottság honlapjának adataiból kiderül, hogy a 2006-ban meghozott intézkedések nyomán 2008-ra hirtelen csökkent az elkövetett terrorcselekmények száma. Míg 2005-ben kétszázötvenegyet regisztráltak (ebböl Csecsenföldön száztizenegy, Ingusföldön harminchat, Dagesztánban hetvenhét, Észak-Oszétiában hét, Cserkeszföldön három, a Kabard- és Balkárföldön nyolc történt), 2006-ban „mindössze” száztizenkettőt követtek el. 2007-ben negyvennyolcat, 2008-ban kettőt (!), 2009-ben hatot, 2010-ben huszonhármat, 2011-ben pedig tízet. 1994 és 2007 között egyebek között megakadályozták a Moszkva-Kalinyingrád vonalon közlekedő vonat robbantásos kisiklatását; a moszkvai tömegközlekedés egyik buszán hatástalanítottak robbanószerkezetet; Voronyezs pályaudvarán is sikerült megelőzni egy robbantásos merényletet; Moszkva közelében megakadályozták egy gázelosztó-állomás felrobbantását, a terroristákat is elfogva. De az orosz fővárosban is sikerült megakadályozni több robbantásos merényletet, tömegközlekedési gócpontokban, nagy forgalmú bevásárlóközpontokban, üzletekben, szórakozóhelyeken. Csecsenföldön 2005-ben elfogtak egy teherautóval közlekedő harcoscsoportot, 1,2 tonna trotillal az autó platóján. 2005-ben a terrorelhárító szervek négyszázötven, 2006-ban nyolcszáznyolcvannégy terrorcselekményt akadályoztak meg. ${ }^{17}$

Oroszországban az elmúlt évben ezerharmincnégy szélsőséges irányultságú büncselekményt szakítottak meg, ez az elmúlt tíz év legkiugróbb ilyen mutatója. E bűncselekmények kétharmada szélsőséges, extremista anyagok internetes terjesztését takarja. A törvényességi felügyeletet ellátó hatóság folyamatosan kutatja a világhálón az extremista honlapokat, letiltva az elérhe-

\footnotetext{
15 Valerij Zsuravel: Terrorizm i antiterrorizm v Rossziji na primere Szevero-Kavkazszkogo regiona (Terrorizmus és antiterrorizmus Oroszországban az észak-kaukázusi régió példáján). http://observer.materik.ru/observer/N9_2013/039_048.pdf

16 Mihejev Ivan Rudolfovics: i. m.

17 Nacionalnüj Antiterroriszticseszkij Komitet, Informacionno-analiticseszkij portal (Nemzeti terrorellenes bizottság, információs-elemző portál). http://nac.gov.ru/
} 
tőségüket. Csak az Oroszországi Föderáció legfőbb ügyészének követelésére több mint háromezer szélsőséges és terrorista tevékenységre, tömeges rendzavarásra felhívó jogellenes információt távolítottak el, és blokkoltak százhatvan, a szíriai jogellenes formációk támogatására eszközöket gyüjtő internetes portált. ${ }^{18}$

\section{A kiváltó okok}

Napjaink oroszországi jogirodalma a terrorizmus következő okait említi ${ }^{19}$ :

a) Az életszínvonal érzékelhető csökkenésével együtt járó társadalmi átrétegződés, leszakadás, olyan szociális-pszichológiai tényezőket hív életre, mint a gonoszság, az irigység, a gyülölet, vagy a múlt utáni nosztalgia.

b) Gazdasági és energiakrízis, áremelkedés, infláció.

c) Egész sor szociális csoport és hivatás válsághelyzete, különösen a harci tapasztalatokkal felvértezett katonáké és robbantási szakembereké.

d) A piaci viszonyok erősítik a migrációt, a vándorló életmódot, a pszichológiai és szakmai leépülést, a személyiség lezüllését előidéző növekvő munkanélküliséget.

e) A fegyverek, a katonai képzettség és az egyszerü lakosok jelentős számának valódi harci cselekményekben (Afganisztán, Csecsenföld) való részvétele következtében kialakuló speciális katonai gondolkodásmód széles körủ elterjedtsége. Emellett a profilváltásra kényszerülő titkosszolgálati munkatársak nagy része nem ritkán bünszervezetekben köt ki, akárcsak a munkát kereső leszerelt fegyveresek többsége.

f) A nyugat-európai kormányellenes szerveződések kínálta minták (például a nyugatnémet Vörös Hadsereg Frakció vagy az olasz Vörös Brigádok).

g) A nemzeti öntudat mértéktelen túlhangsúlyozása (például a Titkos Örmény Hadsereg Örményország Felszabadításáért).

h) A tömegtájékoztatási eszközökből áradó erőszak, egyenlőtlenség, türelmetlenség és a teljhatalmú, féktelen terroristák kultusza.

Ezzel együtt, a nemzetközi és hazai terrorizmus legmeghatározóbb kifejeződésének, a politikai terrorizmusnak politikai okai vannak. Pavel Alekszejevics Kabanov $^{20}$ szerint ezek a következök:

18 Rosszijszkaja Gazeta. http://www.rg.ru/2015/03/31/ekstremizm-anons.html

19 Mihejev Ivan Rudolfovics: i. m.

20 Uo. 
a) Az uralkodó elit megtorló intézkedései az ellenzékkel szemben.

b) Az uralkodó elit erőszakkal kikényszerített, az adott társadalomban tradíciókkal, előzményekkel nem bíró új társadalmi-politikai formációk.

c) Az adott állam belpolitikai konfliktusainak felerösödése.

d) Egy régió két állama politikai érdekeinek összeütközése.

e) A kormányok hibás nemzetpolitikája.

f) Nemzeti különbözőségek céltudatos szítása bizonyos személyek, csoportok, pártok által (példa erre a vahabita mozgalom).

g) A másik állam elleni agresszió, annak elfoglalása az esetek többségében magával hozza a békés lakosság fegyveres ellenállását (partizánok), általuk terrorista módszerek (fontos objektumok felrobbantása, gyújtogatás stb.) alkalmazását.

h) A terrorizmus állami szintủ dicsérete (például terrorizmust támogató arab és egyéb államok).

i) Elégedetlenség külföldi kormányok tevékenységével, amit a külképviseleteik, állampolgáraik és intézményeik elleni terrormerényletekkel fejeznek ki.

Egy oroszországi kutatócsoport álláspontja szerint a hazai szervezett bünözés és terrorizmus sajátos katalizátora a korrupció, valamint a bünözés globalizációja. ${ }^{21}$

\section{A terrorelhárítás rendszere és fó szerve, a Szövetségi Biztonsági Szolgálat}

A terrorizmus elleni küzdelmet megvalósító szubjektumok tevékenységük során a következőkre alapozva fejtik ki tevékenységüket: a szövetségi törvény; a nemzetközi jog általánosan elfogadott elvein és jogi normáin alapuló egyéb jogszabályok; az Oroszországi Föderáció nemzetközi szerződései és az előbbiek alapján kiadott, egyebek közt hatóságok közötti, e tevékenységet szabályozó jogi normák. ${ }^{22}$

Az Oroszországi Föderáció terrorellenes küzdelmében szinte minden központi, területi és helyi fegyveres, illetve igazságügyi struktúrának van feladata. Közülük a legjelentősebbek: a Szövetségi Biztonsági Szolgálat (Federalnaja szlusba bezopasznosztyi Rosszijszkoj federacii; FSZB), az Oroszországi

\footnotetext{
21 Mihejev Ivan Rudolfovics: i. m.

22 Szovet Bezopasznosztyi (az Oroszországi Föderáció biztonsági tanácsa) honlapja.

http://www.scrf.gov.ru/documents/17/30.html
} 
Föderáció legfőbb ügyészsége, Oroszország hírszerző szolgálata, Oroszország védelmi minisztériuma, Oroszország szövetségi határőrsége, az MVD (belügyminisztérium), valamint az MCSSZ (az Oroszországi Föderáció polgári védelmi, rendkívüli helyzetek és katasztrófahelyzetek következményeinek felszámolásában illetékes minisztériuma).

A Szövetségi Biztonsági Szolgálat területi szerveivel együtt, az oroszországi büntetőeljárási jog alapján, operatív nyomozó, szürő-kutató és egyéb tevékenységével felderíti, megelőzi, megszakítja, megakadályozza, feltárja és kivizsgálja a terrorizmus jellemzőit magán viselő cselekményeket, egyebek között a politikai célokat követő bünügyeket, nemzetközi terrortevékenységet. Oroszország szövetségi határőrsége részt vesz a politikai terrorizmus elleni küzdelemben, megelőzve, felfedve, illetve megakadályozva a terroristák átjutását az Oroszországi Föderáció államhatárain, valamint a terrorcselekmények elkövetéséhez szükséges fegyver, löszer, robbanó-, mérgezö-, radioaktív anyag és egyéb, a terrorcselekmények elkövetéséhez szükséges tárgyak, anyagoknak az országba, illetve onnan kiszállítását. Ezenkívül részt vesz a nemzeti tengerhajózás biztonságának fenntartásában az Oroszországi Föderáció kizárólagos gazdasági övezetén belüli vizeken, valamint terrorellenes akciókban.

A belügyminisztérium a terrorista jellegü cselekmények felderítése, megelőzése és megszakítása révén kapcsolódik a terrorellenes harchoz, valamint az Interpollal kapcsolatot tartó nemzeti irodáján keresztül végrehajtva feladatait, együttmüködik különféle államokkal, a terrorizmussal gyanúsított személyek felkutatásában, elfogásában és bíróság elé állításában.

Oroszország hírszerző szolgálata az Oroszországi Föderáció többi hírszerző szervével együtt megelőzi az oroszországi külképviseleteken dolgozók és családtagjaik elleni politikai irányultságú terroristatámadást, továbbá információkat gyüjtenek a külföldi és nemzetközi terrorszervezetek müködéséröl.

Az Oroszországi Föderáció szövetségi örszolgálata a terrorizmus elleni küzdelemből az állami, védett objektumok őrzésével-védelmével veszi ki a részét.

Oroszország védelmi minisztériuma gondoskodik a birtokában lévő tömegpusztító, rakéta- és egyéb fegyverzet; lőszer-, robbanó- és egyéb hadianyagok sértetlenségéről, katonai objektumai védelméről; ezenkívül részt vesz a nemzeti tengeri hajózás és légtér biztonságának szavatolásában, valamint terrorelhárító müveletekben. ${ }^{23}$

23 Uo. 
Az Oroszországi Föderáció legföbb ügyészsége kompetenciájának megfelelöen felügyeletet gyakorol a terrorizmussal kapcsolatos tényekkel, nyomozásokkal összefüggő operatív információgyüjtés törvényessége és minősége felett. ${ }^{24}$

Mint látható, a terrorelhárítás legfontosabb szervezete az FSZB, tevékenységének alapja a terrorcselekmények megszakításának, a benne és az előkészítésében részt vevők felderítésének szükségessége, valamint a terrorizmus veszélyét rejtő információk, események, vagy a cselekményekről történő információgyüjtés nélkülözhetetlensége.

A terrorizmus elleni küzdelem során a helyzethez igazodóan alkalmaznak nyílt és titkos müveleteket, operatív akciókat, a végrehajtó hatalomnak a biztonság fenntartásáról, az operatív nyomozásról szóló jogi normáknak, a büntetőeljárás, a büntetőjognak az FSZB-ről szóló jogszabálynak és egyéb jogi normáknak megfelelően.

A terrorellenes müveletek folyamán az állampolgárok alkotmányos alapjogait, a magánlakás sérthetetlenségéhez, a levéltitokhoz, a magán-telefonbeszélgetésekhez; a postai küldemények, elektronikus levelezés, egyéb személyhez kötött elektronikus kapcsolat sérthetetlenségéhez való jogot korlátozni csak indokolt esetben, a terrorizmus elleni küzdelem szerve vezetöjének, helyettesének kezdeményezésére született bírói határozat birtokában lehet. Halaszthatatlan esetben - huszonnégy órán át - ezt a terrorellenes szerv saját hatáskörben is megteheti, az illetékes ügyész azonnali tájékoztatásával.

Az FSZB terrorellenes speciális rendeltetésű alegységeit - az Oroszországi Föderáció elnökének határozata alapján - az Oroszországi Föderáció területén kívüli terroristák és bázisaik ellen is lehet alkalmazni a föderáció biztonságát veszélyeztető terrorfenyegetés elhárítására. ${ }^{25}$

Az FSZB szervezeti struktúrája az egész ország területére kiterjed, miközben igen erősen centralizált vezetési rendszert foglal magában. Ez azt jelenti, hogy minden tevékenységet - régi szovjet módon - központilag rendelnek el, és központi ellenőrzés mellett vezetnek le. Az orosz elhárítás folyamatosan változik. Vlagyimir Putyin elnök utasításának megfelelően 2003-ban a határőrség az FSZB alárendeltségébe került. ${ }^{26}$

\footnotetext{
24 Mihejev Ivan Rudolfovics: i. m.

25 Federalnaja Szluzsba RF (az Oroszországi Föderáció szövetségi biztonsági szolgálata). http://www.fsb.ru

26 Bagi József: Az Oroszországi Föderáció nemzetbiztonsági szervezetei. Hadtudományi Szemle, 2014/4. http://uni-nke.hu/downloads/kutatas/folyoiratok/hadtudomanyi_szemle/szamok/2014/2014 4/2014_4_bp_bagi.pdf
} 


\section{Megelőzés: tudomány és oktatás a terror ellen}

Az össztársadalmi terrorizmusmegelőző tevékenység a társadalmi gyakorlat lehető legszélesebb, hosszú távú átalakítását célozza a kifejezés átfogóbb értelmében.

A gazdasági szférában: a termelés új technológiákon nyugvó, átgondolt strukturális és beruházási stratégián alapuló fejlesztése, a nemzeti valuta és az egész pénzügyi rendszer megerösítése, az infláció csökkentése stb.

A politikában: új orosz államiság létrejötte és fejlődése, a demokrácia megerősítése, minden hatalmi ág megszilárdítása stb.

Szociális téren: (a szó szük értelmében) nagy antikriminogén hatással bír az éles társadalmi rétegződés felszámolása, az alacsony jövedelmủ állampolgárok támogatása, a családi kötelékek megerősítése, a munkanélküliség negatív következményeinek és az emberek kényszermigrációjának csökkentése stb.

Különös figyelmet kell fordítani a társadalom életének lelki aspektusára, mivel az erkölcs mindig szemben áll a bünözéssel, az erkölcstelenség pedig intenzíven újratermeli. ${ }^{27}$

Íme, egy az Oroszországi Állami Humán Egyetem terroristaellenes honlapján megjelenő konkrét példa a terror elleni tudományos igényü fellépésre:

A terrorizmus napjainkban az utóbbi időben tapasztalt kegyetlensége alapján a civilizáció egyik legföbb veszélye. A terrorveszély a mindennapok valósága, elhárítására mindig készen kell állni. A terrorista számára az emberi élet értéktelen, és mindenki aktív állampolgári kiállása az ellene történő sikeres fellépés elengedhetetlen feltétele.

Aktív tevékenység a terrorizmus ideológiája ellen, és a terrorizmusellenes rendezvények propagandája a fiatalság körében.

A terrorizmus lényegének, társadalmi veszélyének bemutatása, stabil ellenszenv kialakítása az erőszak ideológiája iránt, továbbá a fiatalok megnyerése a terrorizmus, az extremizmus és a nacionalizmus elleni fellépésre.

Tudományos és diákszervezetek bevonása a terrorizmus elleni tevékenység elméleti és módszertani alapjainak kidolgozásába.

A honlap alapvetö feladatai:

- A terrorcselekmények veszélyének bemutatására irányuló céltudatos felvilágosító tevékenység.

27 Mihejev Ivan Rudolfovics: i. m. 
- Az oroszországi fiatalság erkölcsi és hazafias nevelése céljának megvalósításához szükséges körülmények megteremtése, a terrorizmus és az extremizmus iránti ellenszenv kialakítása.

- A terrorizmus keletkezéséhez kapcsolódó, annak embertelen ideológiáját leleplező történelmi, vallási és nemzeti jellegü kérdések bemutatása.

- A társadalom jelentős szociális értékeinek, valamint a nemzetek és vallások közötti békés párbeszéd propagálása.

- A fiatalság nevelése a terrorizmus és az extremizmus ideológiáját elutasító stabil ellenszenvre.

EMLÉKEZTETŐ a lakosságnak a terrorizmus elleni teendőkről:

FIGYELEM!

- Minél figyelmesebben vegyék szemügyre a közelükben álló embertársaikat, különös tekintettel a házuk, társasházuk bejáratánál, padlásán, vagy pincéjében feltünő ismeretlenekre; lakóépületek közvetlen közelében leparkoló, gazdátlan személygépkocsikra!

- Robbanásveszélyes tárgyat (kézigránát, löszer, gránát) vagy gyanús csomagot ne közelítsék meg, mutassák meg a közelben lévő embereknek, megkérve őket, hogy azonnal értesítsék a rendőrséget! Ne engedjenek senkit a közelébe, hogy hozzáérjenek vagy hatástalanítsák!

- Tömegközlekedési eszközökön utazva figyeljenek az elhagyott táskákra, bőröndökre, csomagokra, játékokra és más gazdátlan tárgyakra, amelyek saját készítésủ robbanóanyagot rejthetnek. Ne nyúljanak hozzá, ne próbálják kinyitni, azonnal értesítsék a jármüvezetőt, és figyelmeztessék a gyanús tárgy közelében álló utasokat!

- Minden gyanúsnak talált tárgyról, személyről azonnal értesítsék a rendőrséget! ${ }^{28}$

\section{Az oroszországi terrorizmus nemzetközi összefüggésben}

A XXI. század kezdetén, a 2000 és 2013 közötti időszakban Oroszország a terroristaaktivitás elég magas szintjét mutatta. Alapvetően az észak-kaukázusi szélsőséges terrorizmus következtében Oroszország a vizsgált időszak első tíz évében a terrorizmus által leginkább érintett első tíz ország közé tarto-

28 Nauka i obrazovanyije protyiv terrora (Tudomány és oktatás a terror ellen). http://www.rsuh.ru/antiterror/ 
zott a világon, a kilencedik helyet elfoglalva, egyetlen európai országként, a többi, jellemzően szegény országhoz képest magas éves bevétellel. A 2001. szeptember 11. utáni tízéves időszak legnagyobb oroszországi terrorcselekménye, a 2004-es beszláni, méretét tekintve a harmadik lett a világban. Az utóbbi tíz év terroristaaktivitását vizsgálva viszont más országokhoz viszonyítva javult a helyzet Oroszországban, az utóbbi húsz év adataival összevetve. Összességében azonban az Oroszországi Föderáció stabilan a terrorcselekmények által leginkább veszélyeztetett első húsz ország közé tartozik. ${ }^{29}$

Az objektívebb képhez hozzá tartozik, hogy a Magyarország közvetlen szomszédságában kialakult ukrán-orosz konfliktusban mindkét fél állami terrorizmussal vádolja a másikat, illetve a saját ellenzék a hatalmon lévő kormányt. „, Az oroszországi terrorizmus célja nem a fényes jövö, hanem a fényes múlt. A Budapesti memorandum megsértésével Putyin nemzetközi büntettet követett el, míg az USA és Nagy-Britannia, nem teljesitve vállalásaikat, társtetteseivé váltak. " ${ }^{30}$ Ukrajna 1994-ben lemondott a világon harmadik legnagyobb atomarzenáljáról, cserében garanciát kapva az ország függetlenségére, területi épségére. Oroszország szerint, miután a memorandumot nem ratifikálták az aláíró felek parlamentjei, ezért nincs nemzetközi szerződésnek megfelelö joghatása. ${ }^{31}$

„Az orosz terroristák Luhanszkban és Szlavjanszkban gyermekeket használnak élö pajzsként. ${ }^{{ }^{2} 2} \mathrm{Az}$ ukrán belügyminisztérium volt szóvivője szerint az ukrajnai eseményeket ,Egyesek népfelkelésnek, mások terrorizmusnak nevezik, de úgy gondolom a terrorizmus nem jó terminológia a helyzetre, hiszen a tiltakozó feleket az ukránok nagy része támogatja" ${ }^{33}$. Az előbbiek alapján talán az szürhető le a legnagyobb biztonsággal, hogy egy állam szempontjából azt tekintik terrorizmusnak, ami az adott állam - és akár a határain kívüli(!) globális érdekei - ellen irányul.

\footnotetext{
29 Jekatyerina Andrejevna Sztyepanova: Osznovnüje tendenciji v oblasztyi szovremennovo terrorizma (A modern terrorizmus alapvető tendenciái). http://pircenter.org/media/content/files/12/14116655730.pdf

30 Argument. http://argumentua.com/stati/terrorizm-na-sluzhbe-gosudarstva

31 http://www.km.ru/v-rossii/2014/03/01/mezhdunarodnaya-politika/733609-pochemu-ne-byl-ratifitsirovan-budapeshtskii-memo

32 Terrorisztü v Ukraine prikrüvajutsza c gyetymi (A terroristák Ukrajnában gyerekekkel fedezik magukat). http://by24.org/2014/06/04/children_are_a_shield_for_russian-terrorists_in_slaviansk_ and_lugansk/

33 Szegodnya. http://www.segodnya.ua/politics/pnews/slovo-terrorizm-v-ukraine-seychas-nelzya-primenyat-polishchuk-497186.html
} 


\section{Összegzés}

Napjainkban általánosan elfogadott tény, hogy a terrorizmus elleni küzdelem csak a világ országainak együttes fellépésével lehet eredményes. Ennek elsősorban a terrorizmus transznacionális jellege az oka.

Az oroszországi hatékony terrorelhárítás-tervezésnek szintén tekintetbe kell vennie a terrorizmus bonyolult, sokoldalú társadalmi jelenség mivoltát. Az ellene folytatott küzdelemben különös jelentőséggel bír a leginkább érintett belbiztonsági, fegyveres, igazságügyi és kormányzati szervek minél szorosabb, összehangoltabb együttmüködése, a nemzetközi környezet és terroristaellenes együttmüködés további konszolidációja. ${ }^{34}$

Mint az előbbiekben láthattuk, az állami, politikai, nacionalista, vallási indíttatású terrorizmus oroszországi történetében is példátlan korszak volt a XX. század. Hatásai máig érezhetők az ország társadalmában. Totalitárius zsarnokok, politikai kalandorok, vallási fanatikusok, nacionalista szeparatisták, a bünös emberiség őrült vagy félörült megjavítói és egyszerü jöttmentek váltak ártatlan embercsoportok, tömegek, milliók halálának okozóivá. Mára a terrorizmus mindenféle formájában, megnyilvánulásában, mértékében, intenzitásában, embertelenségében és kegyetlenségében a legélesebb és legégetőbb, globális jelentőségü problémává vált. Anthony de Mello szavaival: „Az emberek pénzért és hatalomért is ölnek, de legkegyetlenebb gyilkosok azok, akik a saját gondolataikért ölnek, mert az ideák háborújában az emberek az áldozatok..." ${ }^{35}$

34 Mihejev Ivan Rudolfovics: i. m.

35 De MELLO Anthony: Abszurd egypercesek. Kecskemét, 2005, Korda kiadó, 17 p., ISBN: 963-9554$12-\mathrm{x}$ 